\title{
EFFECT OF RESERVOIR HETEROGENEITIES ON ELASTIC AND SEISMIC PROPERTIES OF LOWER CRETACEOUS SAND INTERVALS, LOWER INDUS BASIN OF PAKISTAN
}

\author{
Perveiz KHALID*, Muhammad ARSHAD, Muhammad Irfan EHSAN, \\ Aziz AHMAD and Shahzada KHURRUM
}

Institute of Geology, University of the Punjab, 54590 Lahore, Pakistan

*Corresponding author's e-mail: perveiz.geo@pu.edu.pk

\begin{tabular}{l} 
ARTICLE INFO \\
\hline Article history: \\
Received 1 June 2021 \\
Accepted 3 August 2021 \\
Available online 6 September 2021 \\
\hline
\end{tabular}

\section{Keywords:}

Petrophysical analysis

Rock physics analysis

Lower Indus Basin

Reservoir heterogeneities

\begin{abstract}
The use of rock physics modeling and petrophysical analysis has become an integral part of quantitative seismic interpretation. In the present study, the above-mentioned techniques are applied to the reservoir interval of Basal Sand of Cretaceous age widely distributed in the Lower Indus Basin of Pakistan. The data used for this purpose consists of complete suits of wireline logs from four well A, B, C and D. The primary goal of this work is to understand the trends of seismic parameters such as P-wave velocity $\left(V_{P}\right)$, S-wave velocity $\left(V_{S}\right)$, bulk modulus, bulk density as a function of fluid saturation and porosity in this sand interval. Petrophysical analysis based on well logs is used to obtain petrophysical properties such as porosity, the volume of shale, fluid saturation, P-wave velocity $\left(V_{P}\right)$, S-wave velocity $\left(V_{S}\right)$ and density at reservoir conditions. The results show that seismic parameters are very sensitive to fluid saturation, fluid types and rockforming sediments. Reservoir porosity and fluid saturation control the elastic response of Basal Sand due to which seismic velocities decrease with an increase in porosity and fluid saturation.
\end{abstract}

\section{INTRODUCTION}

The Indus Basin is the most productive hydrocarbons zone in Pakistan (Khalid et al., 2014a; Khalid et al., 2016; Azeem et al., 2018). Based on tectonic and geological settings this basin has been separated into lower, middle and upper parts (Wandrey et al., 2004; Yasin et al., 2021). The sandstone interval of the Lower Goru Formation of the Lower Cretaceous age is a hydrocarbon-containing zone that has been explored for the last thirty years (Jamil et al., 2012; Hussain et al., 2017a; Hussain et al., 2017b; Khalid et al., 2018). Within this formation, sandstone occurs in different litho-stratigraphic units referred to as the Upper, Middle, Basal, and Massive Sands (Wandrey et al., 2004).

Hussain et al. (2016 a, b) discussed the reservoir character of Basal Sand zones of the Lower Goru Formation by using wireline logs. However, these authors did not study the seismic signatures of these sand intervals. The focus of these workers was only to investigate the hydrocarbon potential of these sand intervals with the help of isoparametric maps. They computed the net pay thickness of these intervals in this area and computed 5-10 m net pay thickness of the Basal Sand interval with a net-to-gross ratio of $0.2-0.8$. Moreover, the rock physics response of these intervals, which quantifies the influence of pore fluids on the effective properties of the rock-fluid composite was also not investigated by previous workers.

To find out the seismic and elastic behavior of hydrocarbon-bearing reservoir rock having the hydrocarbon, different kinds of rock physics models (Khalid et al., $2014 \mathrm{~b}$ ) and petrophysical techniques are in practice (Khalid et al., 2016), including Gassmann's fluid substitution modeling. The petrophysical analysis is used to define the hydrocarbon and water-bearing zones in a formation by evaluating the wireline log data and to determine the quantities of probable hydrocarbon and water accumulations in the reservoir zones (Asquith and Krygowski, 2004; Asquith and Gibson, 1982; Bateman, 1985). A suitable rock physics modeling approach is required to compute reservoir parameters (Nguyen and Nam, 2011; Saxena et al., 2013; Khalid and Ahmed, 2016) The variation of elastic parameters and fluid saturation intensively affects the velocities and densities (Li, 2009; Mavko et al., 2009). Seismic signatures and elastic parameters are the necessary properties that are estimated from well log analysis. Similarly, the fluid substitution model (Gassmann, 1951; Khalid et al., 2014b) is also used to anticipate the bulk modulus of pore filled with the fluid-rock unit and effective density that is further used to compute seismic velocities at in-situ conditions (Ahmed et al., 


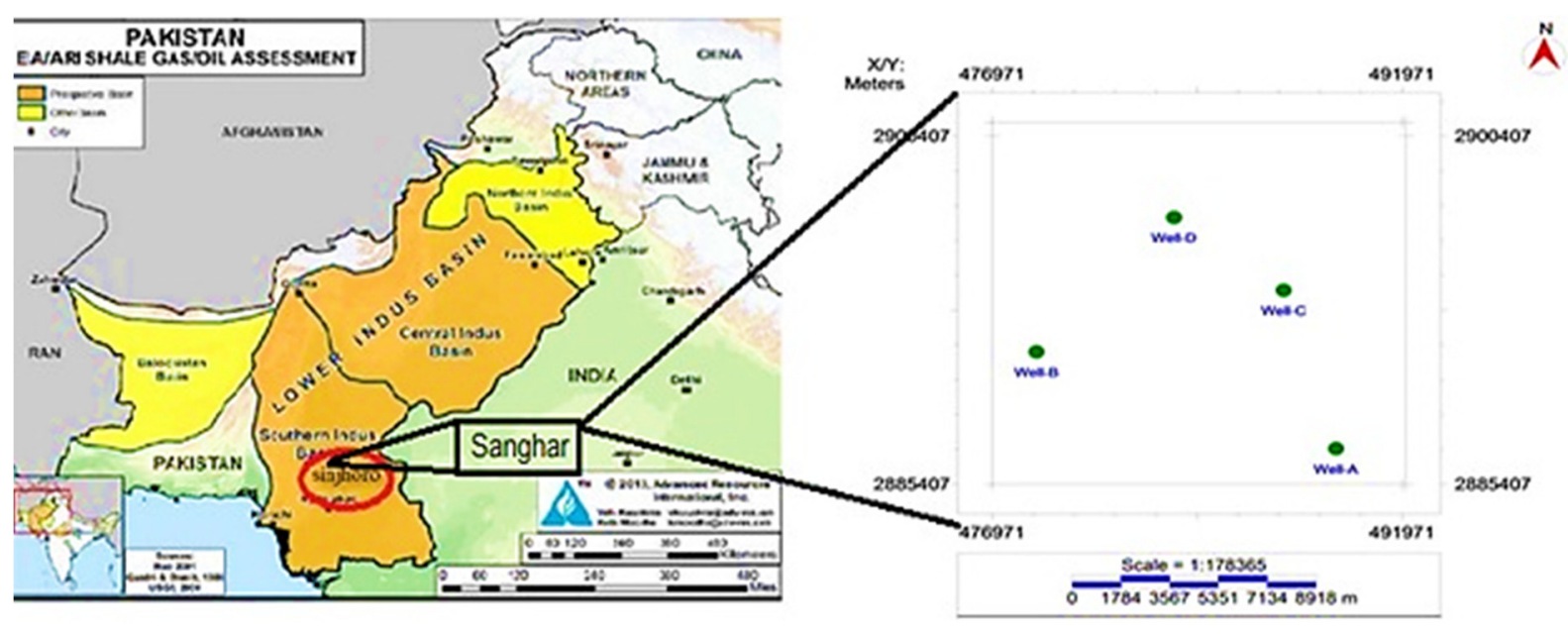

Fig. 1 Location of the study area (Sanghar field). Base map showing the positions of wells used in the current study (after Kazmi and Jan, 1997).

2018). The sensitivity behavior of seismic signature with the variation of elastic parameters comprehensively was studied by various workers (Ehsan et al., 2016a, b, c; Khalid and Ahmed, 2016). For quantitative seismic interpretation, rock physics modeling plays a key role to delineate the concentration of pore fluids with respect to elastic properties of rock (Nguyen and Nam, 2011). This technique is also used to forecast the seismic properties and petrophysical measurements with the help of wireline logs data (Telford et al., 1990; Khalid et al., 2016), which provide us good connectivity between physical properties and the observed seismic response (Batzle and Wang, 1992). The objective of modeling is to understand the seismic behavior of the reservoir with respect to petrophysical response. This seismic behavior is affected by the fluid type and its properties such as density, porosity, bulk modulus, shear modulus, and viscosity. The saturation of water is calculated with help of Archie's model (Archie, 1942) and integrated with the Indonesian model (Levaux and Poupon, 1971) to deduce more reliable results in reservoir intervals.

\section{GEOLOGY OF STUDY AREA}

Based on petroleum prospects and exploration history Pakistan is divided into two sedimentary basins: Baluchistan and Indus Basins. The Indus Basin is extended into NE-SW direction (Kazmi and Jan, 1997) and is categorized by a large platform region with a gentle slope. The collision of the Indian Plate with the Eurasian plate caused segregating of Indus Basin into two portions named as an upper and lower basin (Ahmad et al., 2012; Khan and Liu, 2019). The study area is situated in Thar Platform, which is a part of the Lower Indus Basin that is surrounded by the Indian Shield in the east and marginal zone of the Indian plate to the west. It comprises five units: Karachi Trough, Thar Platform, Kirthar Fordeep and
Fold Belt. The study area is identified as an extensional basin having horst and graben structures in a series (Killing et al., 2002). Thus, the structural style of the area is evolved by the three post-rifting tectonic activities, which are: uplifting and erosion of Late Cretaceous, NNW-SSE oriented wrench faults originated from the basement, and the continuous uplifting of Jacobabad and Khairpur Highs started from Late Tertiary (Ahmad et al., 2012). Figure 1 shows the base map of the study area. Thar platform is moderately sloping which is controlled by the basement topography whereas the Nagar Parker High is its surface outcrop. The most prominent and primary tectonic event occurred under the action Late Cretaceous uplifting close to the famous K-T boundary (base Tertiary unconformity). The majority of the basement-rooted wrench faults were terminated against this K-T boundary as mapped on seismic sections (Azeem et al., 2018). The next tectonostructural activity was related to the Late Eocene-Oligocene wrench faulting under the action of active collision between the Eurasian and Indian Plate (Zaigham and Mallick, 2000; Ahmed et al., 2004). The last tectono-structural episode is the active uplifting of Jacobabad/Khairpur High started from the Late Tertiary. The sands of the Lower Goru Formation were deposited deep under the action of this uplifting whereas non-reservoir intervals were positioned up-dip to form geological traps favorable for hydrocarbon accumulation (Azeem et al., 2018). In this episode, the development of structural and stratigraphic traps and secondary hydrocarbon migration has been taken place.

The exploration and production history of the study area is spanned more than 60 years with good production of oil and gas. Borehole drilling and wireline logging along with seismic reflection data indicate that a complete petroleum system was deposited during the Cretaceous period. The Lowe 
Goru Formation of the Lower Cretaceous age has variable lithology with alternate layers of shale and sand (Hussain et al., 2017a). The sand intervals have been acting as reservoirs whereas the shales of the Upper Goru Formation are acting as cap rocks. However, the underlying shales of the Sember Formation are acting as good source rock.

\section{METHODOLOGY AND DATA SETS}

The data used for this research work includes a complete suite of conventional wireline logs such as caliper, resistivity (LLD, LLS), gamma ray (GR), sonic transit travel time (DT), neutron porosity (NPHI), density (RHOB) and spontaneous potential (SP) logs containing formation tops, temperature data of four wells A, B, C and D. In first most steps, all useable wireline logs were corrected and calibrated. The methodology workflow covered two units: the first one is the petrophysical analysis and the second is rock physics modeling. The petrophysical analysis is used to determine the presence of a volume of shale, effective and total porosity, types of fluid present in the pore spaces and their saturation, the resistivity of the reservoir rock. These parameters are used for the estimation of the physical properties of the saturated rock which are computed in the next step.

\subsection{FORMULATION OF PETROPHYSICAL PARAMETERS FROM WIRELINE LOG}

The petrophysical analysis is performed to differentiate the reservoir facies from non-reservoir and to delineate the significant hydrocarbon potential bearing zones in the reservoir. The volume of shale $\left(V_{s h}\right)$, permeability $(k)$, reservoir porosity $(\phi)$, water saturation $\left(S_{w}\right)$, and seismic velocities are the basic parameters to define reservoir character and quality of the selected zone of Basal Sand of the Lower Goru Formation. Gamma ray index derived to estimate the volume of shale with the help of the following relation:

$I_{G R}=\frac{G R_{\log }-G R_{\min }}{G R_{\max }-G R_{\min }}$

where $G R_{\log }$ is gamma ray log reading at any depth of interest, $G R_{\max }$ is the maximum value, and $G R_{\min }$ minimum value of GR log in the clean sand interval. In the present study, $V_{s h}$ is calculated by using gamma ray index and relationships of Larionov (1969), Steiber (1970) and Clavier et al. (1984). Larionov (1969) suggested separate formulas for younger and older rock. The following relationship is used to compute the volume of shale

$V_{S H}{ }^{L}=0.33 *\left(2^{2 I_{G R}}-1\right)$

The next important parameter is porosity, which has been calculated from density log (RHOB). Mathematical relationship to compute porosity from density log is given below:

$\phi_{D}=\frac{\rho_{m}-\rho_{b}}{\rho_{m}-\rho_{\text {fluid }}}$
Where $\phi_{D}$ is porosity, $\rho_{m}$ is the density of matrix, $\rho_{b}$ bulk density and $\rho_{\text {fluid }}$ is the density of reservoir fluid. The average porosity is computed by using porosities derived from neutron and density logs by using the following relationship:

$\phi=\frac{\phi_{D^{+}} \phi_{N}}{2}$

The pore spaces of the reservoir are occupied by the fluids. $S_{w}$ is calculated from Archie's formula (Archie, 1942):

$S_{w}=\sqrt[n]{\frac{a \times R_{w}}{\phi_{\text {average }}{ }^{m} \times R_{t}}}$

Here $S_{w}, \phi, R_{t}$ are saturation of water, true resistivity, and the average porosity respectively. $R_{w}$ is the resistivity of water, $a$ is the wettability factor with constant value 1 and $m$ is the cementation factor having constant value 2 . We derived the $R_{\mathrm{t}}$ from the resistivity $\log$ (LLD and LLS) and $R_{w}$ from the SP log:

$R_{t}=1.7 * L L D-0.7 * L L S$

$R_{w}=10^{\wedge} K * \log * R_{m f}+S P / K$

The input parameters $K, R_{m f}$ and $T_{f m}$ are calculated as:

$R_{m f}\left(T_{f m}\right)=\frac{R_{m f}\left(T_{s r f}\right) *\left(T_{s r f}+6.67\right)}{T_{f m}+6.67}$

$T_{\text {fm }}=$ Total depth $*$ gradient $+T_{\text {srf }}$

$K=61+0.133 * T_{\text {srf }}$

Archie's relation was used for the clean sand while the Indonesian equation (Hussain et al., 2017b) was used for shaly sand. There are rare chances for a reservoir to have clean sand, so we used the Indonesian equation (Levaux and Poupon, 1971) for the estimation of water saturation:

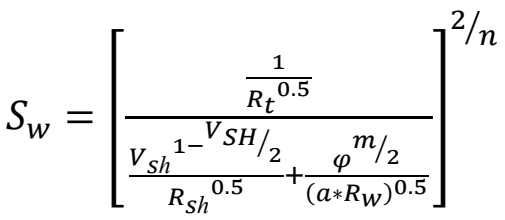

Here $R_{s h}$ is the resistivity of shale measured in ohm meter.

\subsection{FORMULATION OF ROCK PHYSICS ANALYSIS}

Rock physics is a key to understand reservoir rocks by their physical properties and the relationship between seismic and petrophysical properties of fluidbearing rocks. Physical properties are density, porosity, bulk modulus, shear modulus, and viscosity. The bulk modulus of saturated porous sand is a complex function of various parameters such as fluid saturation, fluid type, rock matrix, rock minerals, fluid density and porosity. (Khalid et al., 2018). The bulk modulus of a saturated rock is estimated by using 
Table 1 Input parameters used for rock physics modeling.

\begin{tabular}{lcccc}
\hline Input Rock & Well A & Well B & Well C & Well D \\
Physics Parameters & & & & 0.15 \\
\hline $\mathrm{V}_{\text {clay }}$ & 0.13 & 0.14 & 0.85 & 0.86 \\
$\mathrm{~V}_{\text {Quartz }}$ & 0.87 & 0.86 & 37 & 37 \\
$K_{\text {Quartz }}(\mathrm{GPa})$ & 37 & 37 & 20.44 & 20.33 \\
$K_{\text {dry }}(\mathrm{GPa})$ & 21.30 & 21.60 & 21 & 21 \\
$K_{\text {clay }}(\mathrm{GPa})$ & 21 & 21 & 2580 & 2580 \\
$\rho_{\text {clay }}\left(\mathrm{kg} / \mathrm{m}^{3}\right)$ & 2580 & 2580 & 2650 & 2650 \\
$\rho_{\text {Quartz }}\left(\mathrm{kg} / \mathrm{m}^{3}\right)$ & 2650 & 2650 & 33.90 & 34.09 \\
$K_{\text {matrix }}(\mathrm{GPa})$ & 34.29 & 34.09 & 2.53 & 2.51 \\
$K_{\text {brine }}(\mathrm{GPa})$ & 2.49 & 2.47 & 186.63 & 174.71 \\
$\rho_{\text {gas }}\left(\mathrm{kg} / \mathrm{m}^{3}\right)$ & 162.62 & 0.05 & 0.079 & 0.070 \\
$K_{\text {gas }}(\mathrm{GPa})$ & 0.063 & 0.003 & 0.003 & 0.003 \\
$\mathrm{~S}(\mathrm{Salinity})$ & 0.003 & 0.6 & 0.6 & 0.6 \\
Specific Gravity & 0.6 & & & \\
\hline
\end{tabular}

Gassmann's equation (Gassmann, 1951). The equation of Gassmann is,

$K_{\text {sat }}=K_{\text {frame }}+\frac{\left(\frac{1-K_{\text {frame }}}{K_{\text {matrix }}}\right)^{2}}{\frac{\varphi}{K_{\text {fl }}}+\frac{(1-\varphi)}{K_{\text {matrix }}}+\frac{K_{\text {frame }}}{K_{\text {matrix }}^{2}}}$

Where $K_{\text {sat }}$ is the bulk modulus of incompressibility of fluid saturated or partially saturated reservoir rock, which is a function of dry rock modulus $\left(K_{\text {frame }}\right)$, bulk modulus of pore fluid $\left(K_{f l}\right)$, bulk modulus of rock-forming minerals $\left(K_{\text {matrix }}\right)$ and $\phi$ is the porosity of the reservoir rock. $K_{\text {matrix }}$ was calculated from Voigt-Reuss-Hill (VRH) averaging technique (Voigt, 1910; Reuss, 1929; Hill 1952).

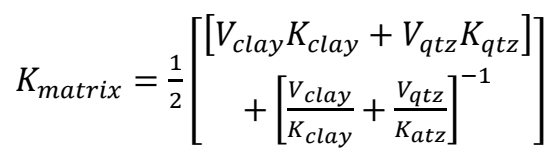

$K_{q r t z}$ is the bulk modulus of quartz mineral. Table 1 shows detail of the rock physics parameter we have used in our modeling. Wood's equation (Wood, 1941) is used to calculate the bulk modulus of incompressibility of multi-phase fluids

$K_{f}=\left[\sum_{i=1}^{n} \frac{s_{i}}{K_{i}}\right]^{-1}$

Here $S$ and $K$ are saturation of fluid in reservoir zone and bulk modulus of liquid (oil, gas and brine) respectively. The index $i$ is the number of fluid phases while $n$ is the total number of fluid phases of the reservoir rock. By using bulk modulus and the bulk density of the isotropic material the velocities of P-and $\mathrm{S}$ waves were estimated by the following equations:

$V_{p}=\sqrt{\frac{K_{s a t}+4 /{ }_{3} \mu_{\text {sat }}}{\rho_{\text {eff }}}}$

and

$V_{s}=\sqrt{\frac{\mu_{s a t}}{\rho_{e f f}}}$
Here $\mu_{\text {sat }}$ is the shear modulus of saturated rock and $\rho_{\text {eff }}$ is the effective density of saturated rock determine as,

$\rho_{e f f}=(1-\varphi) \rho_{m a t}+\varphi \rho_{f}$

The pore fluids density and density of matrix were calculated here:

$\rho_{f l}=S_{w} \rho_{w}+S_{g} \rho_{g}$

$\rho_{\text {mat }}=V_{\text {clay }} * \rho_{\text {clay }}+V_{\text {qrtz }} * V_{\text {qrtz }}$

Here $S$ and $\rho$ denote the saturation and density of the fluid phases respectively.

\section{RESULTS \\ 4.1. PETROPHYSICAL EVALUATION OF SAND INTERVALS}

The petrophysical evaluation of the wireline logs run in the Basal Sand intervals encountered in all wells is demonstrated in Figure 2. These intervals encountered at depth vary from 2800-2910 m having a gross thickness of 15-35 m. It is evident that GR log shows less deflection against the sand intervals. The water saturation computed from both Archie's and the Indonesian equations shows very close agreement with each other. However, in clean sand intervals where clay contents are smaller, both curves show some deflection whereas in the clay-rich zone Archie's equation overestimates the water saturation. The total and effective porosity of sand intervals varies from $14 \%-16 \%$ and $9 \%-11 \%$ respectively, which indicates that the reservoir is consolidated. It is observed that zone of low values of gamma ray log contains the higher values of hydrocarbon, which is confirmed from the corresponding log such as volume of shale have lower values in well C and D. DT log has low values in non-hydrocarbon containing zone and has higher values in hydrocarbon-bearing zones. The porosity log has higher values, where the volume of shale is low as shown in Figure 2 well C and D. 


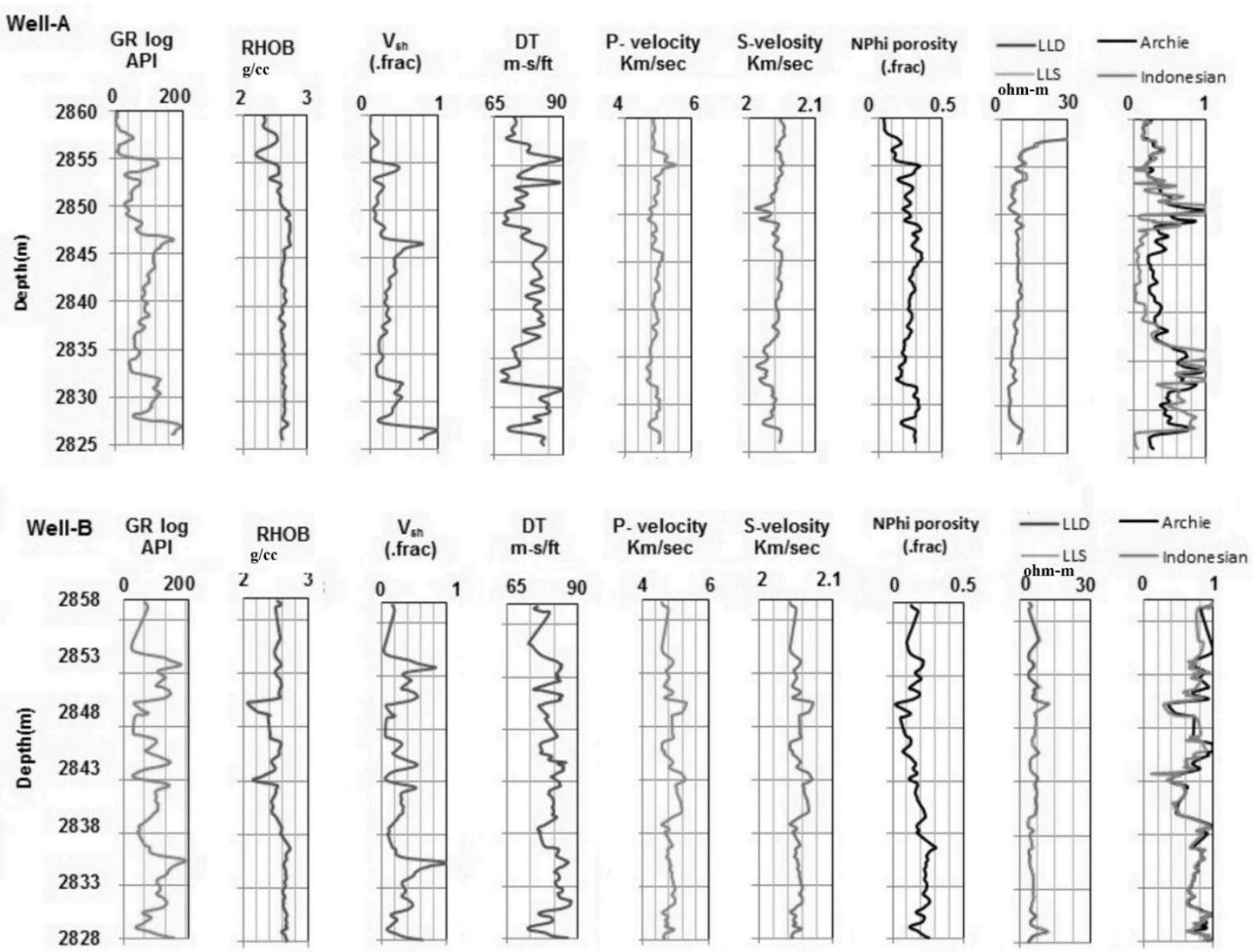

Fig. 2 a Input log curves and estimated petrophysical parameters such as shale volume, porosity, P-wave velocity and water saturation for well A and B.

\subsection{ROCK PHYSICS ANALYSIS}

Rock physics is the key to understand reservoir rocks by their physical properties; these physical properties show the effect of the seismic wave passing through the rocks. It is a basic and useful technique for the study of 3D seismic as these models can help in the prediction of different properties of porous rocks at the production stage (Khalid and Ghazi, 2013). 3D model for the effective density as a function of porosity of wells A, B, C and D is shown in Figure 3. It is evident from the figure that the values of density are the inverse function of formation porosity and fluid saturation. The 3D model for the bulk modulus of the saturated rock $\left(K_{\text {sat }}\right)$ as a function of porosity and fluid saturation of wells A, B, C and D is shown in Figure 4. It is evident from the figure that the values of $K_{\text {sat }}$ in all wells are high about $30 \mathrm{GPa}$ but as the saturation is increased the value of $K_{\text {sat }}$ decreased to $10 \mathrm{GPa}$. When the porosity values increase from $8 \%$ to $26 \% K_{\text {sat }}$ they show decreasing trend as shown in Figure 4.

The seismic wave velocities $\left(V_{P}\right.$ and $\left.V_{S}\right)$ computed by using equation (12) are a direct function of effective density and saturated bulk moduli. 3D cross plots of these velocities as a function of formation porosity and pore fluid saturation are demonstrated in Figures 5 and 6 for $V_{P}$ and $V_{S}$ respectively. It is clear from the figures that $V_{P}$ is a decreasing function of porosity and fluid saturation whereas $V_{S}$ increases with an increase in porosity. However, it is less dependent on fluid saturation as the shear modulus is independent of fluid saturation. This behavior of $V_{S}$ is due to a decrease in effective density with an increase in porosity and fluid saturation. Initially, the value of $V_{P}$ is high when porosity is about $8 \%$ as a function of water saturation in well A, B, C and $\mathrm{D}$. Since water has higher density as compared to hydrocarbon, therefore, P-wave velocity has an increasing trend by an increase in water saturation in all well $\mathrm{A}, \mathrm{B}, \mathrm{C}$ and $\mathrm{D}$. On the other hand, the maximum decrease in $V_{S}$ with 0 to $100 \%$ fluid saturation is merely $200 \mathrm{~m} / \mathrm{s}$, which is not easily noticeable on multicomponent seismic reflection data.

\section{CONCLUSIONS}

The petrophysical analysis done based on wireline $\operatorname{logs}$ of four wells shows that the sand intervals of the Lower Goru Formation in the Lower Indus Basin have very good reservoir potential as confirmed by previous studies. These intervals are hydrocarbon saturated with average porosity of 


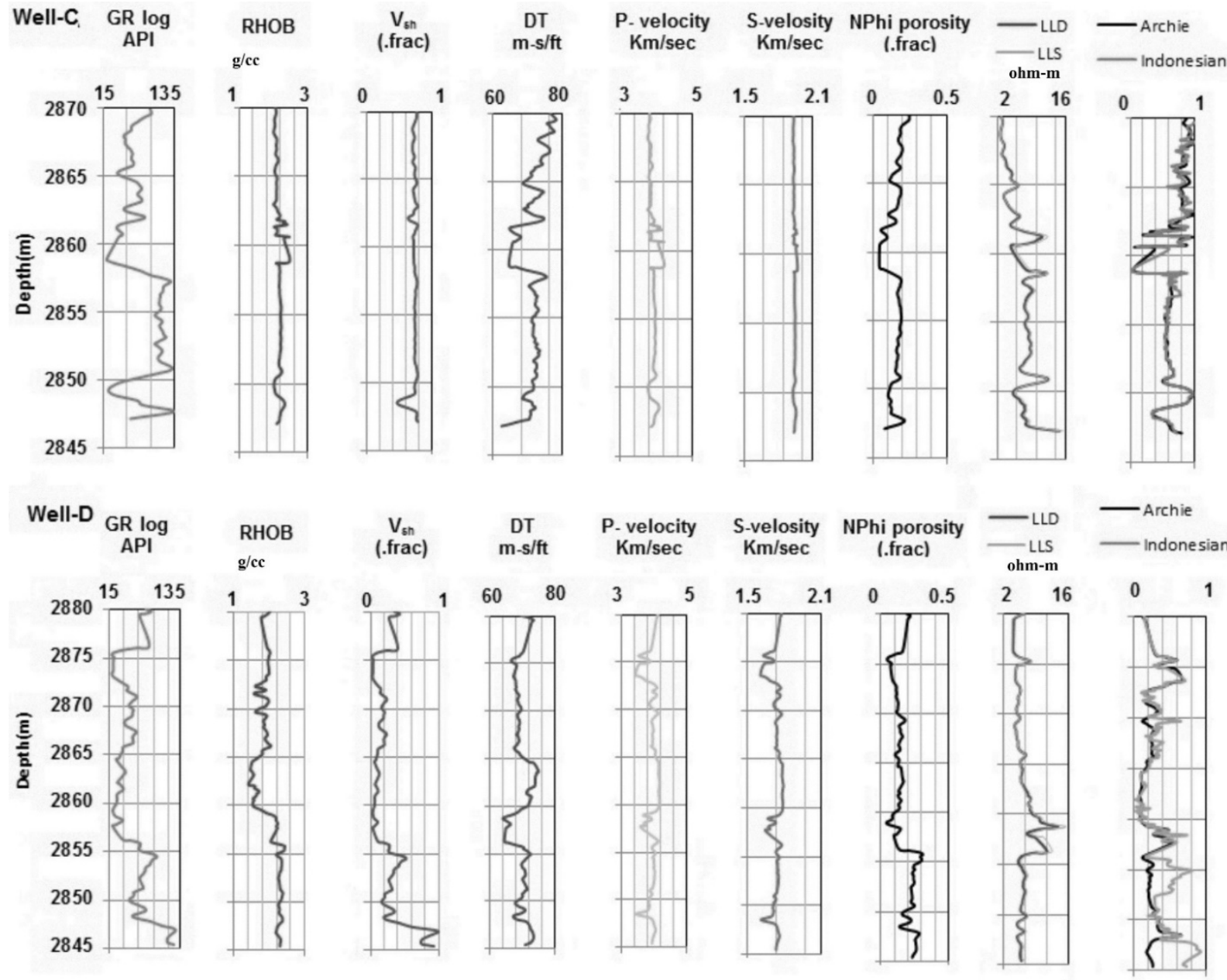

Fig. 2 b Input log curves and estimated petrophysical parameters such as shale volume, porosity, P-wave velocity and water saturation for well C and D.
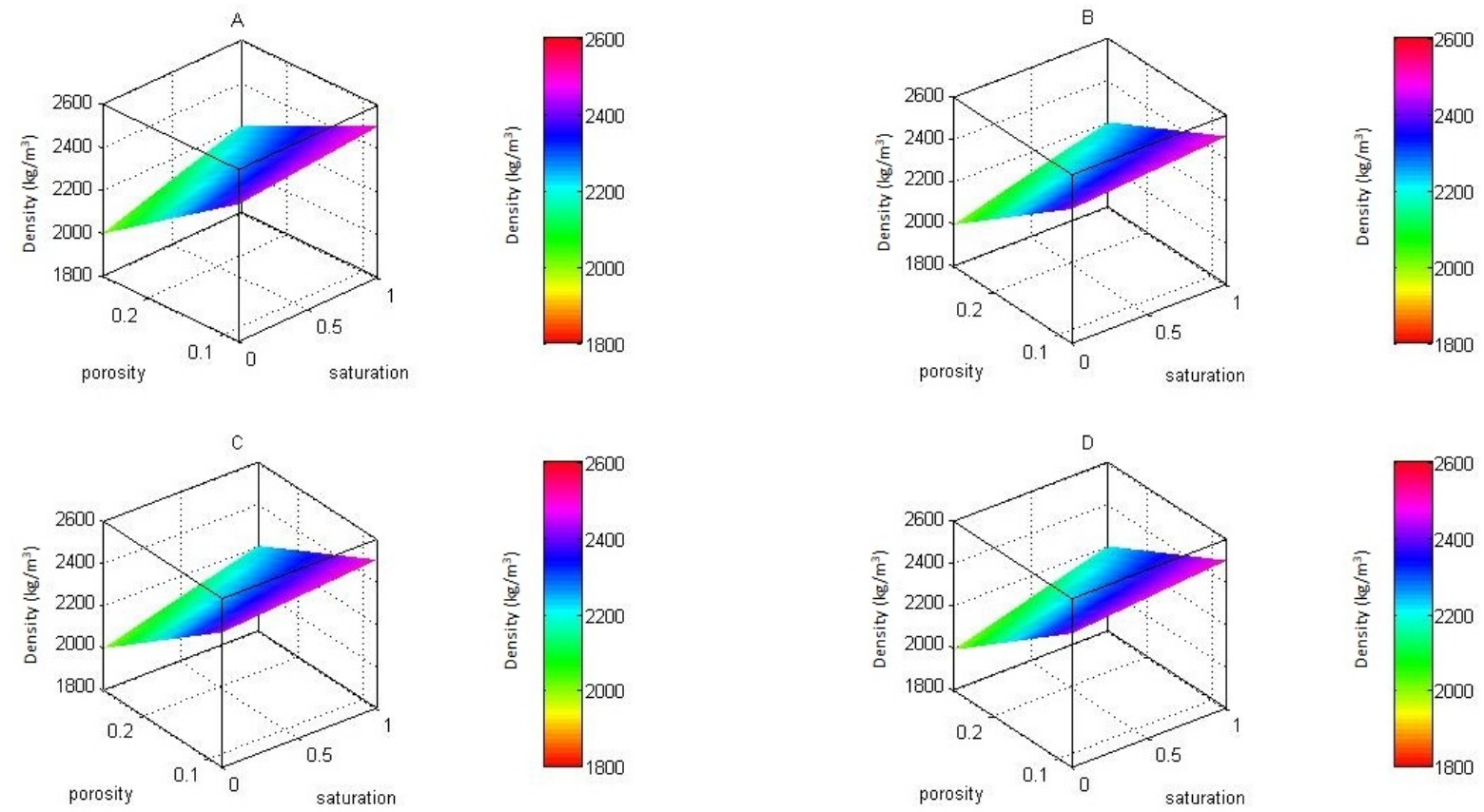

Fig. 3 Impact of fluid saturation and porosity on the effective density of sand intervals in well A, B, C and D. 

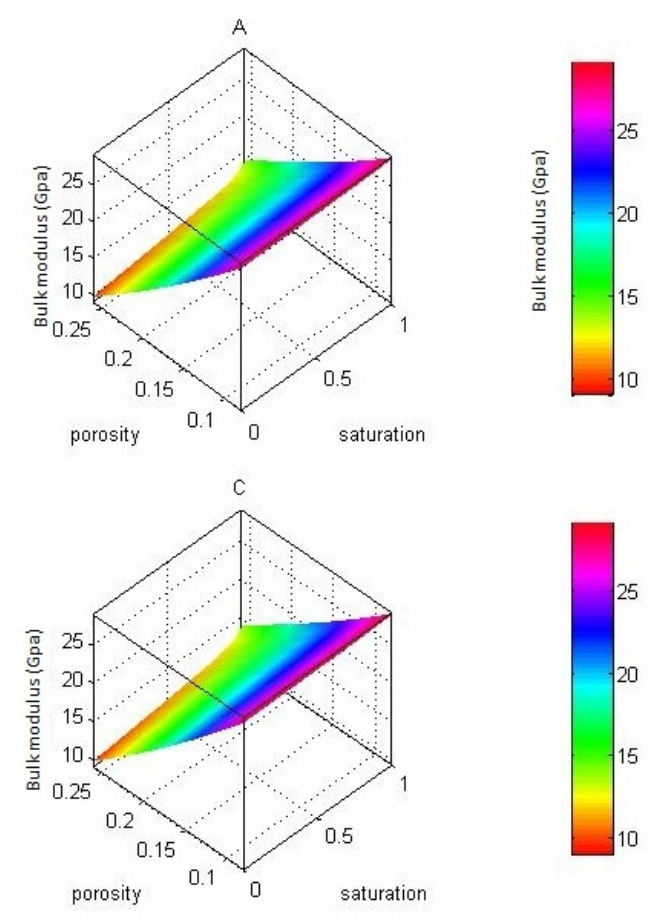

Fig. 4 Effect of fluid and porosity-related heterogeneities on bulk modulus of saturated sand intervals encountered in well A, B, C and D.
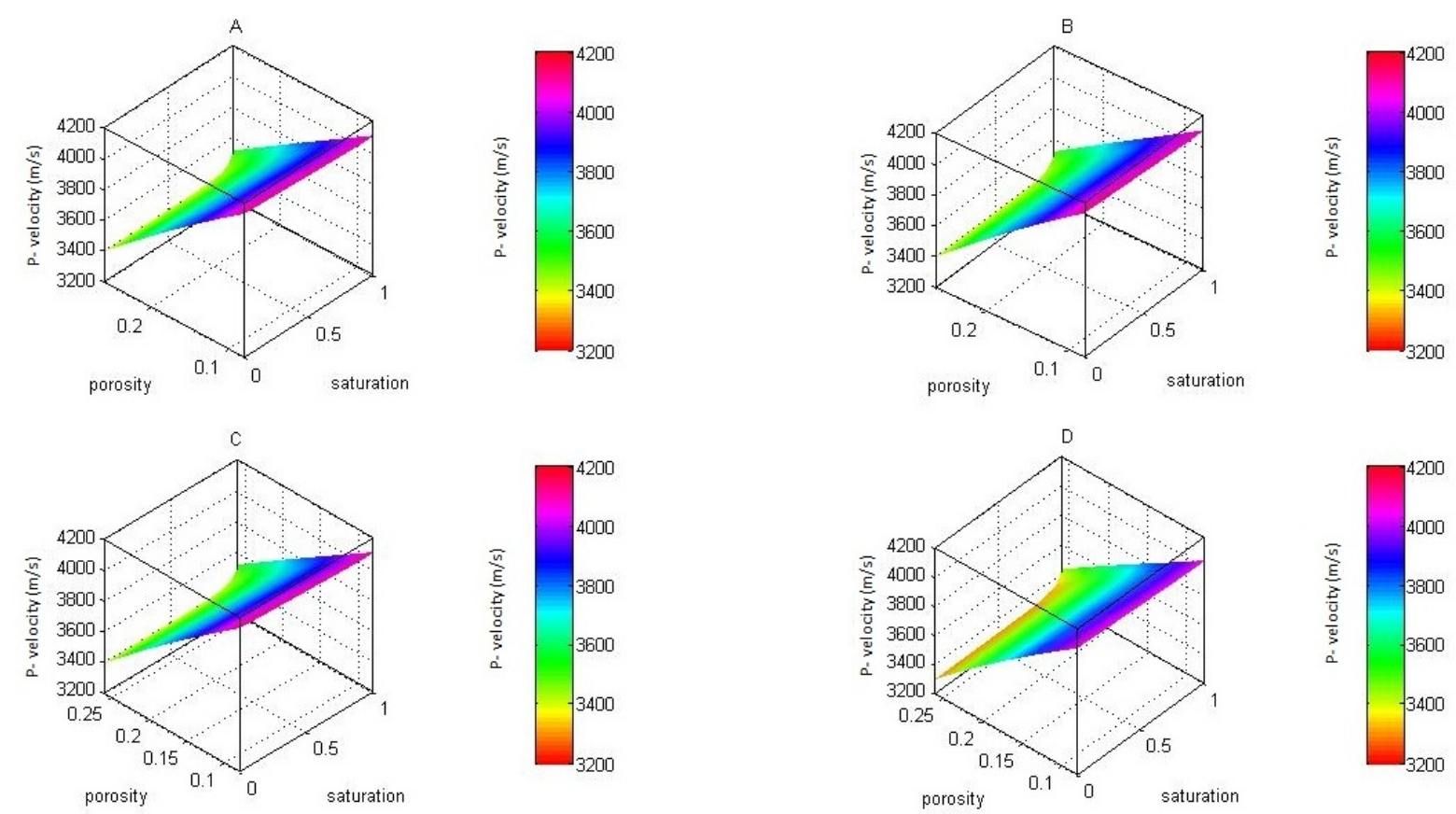
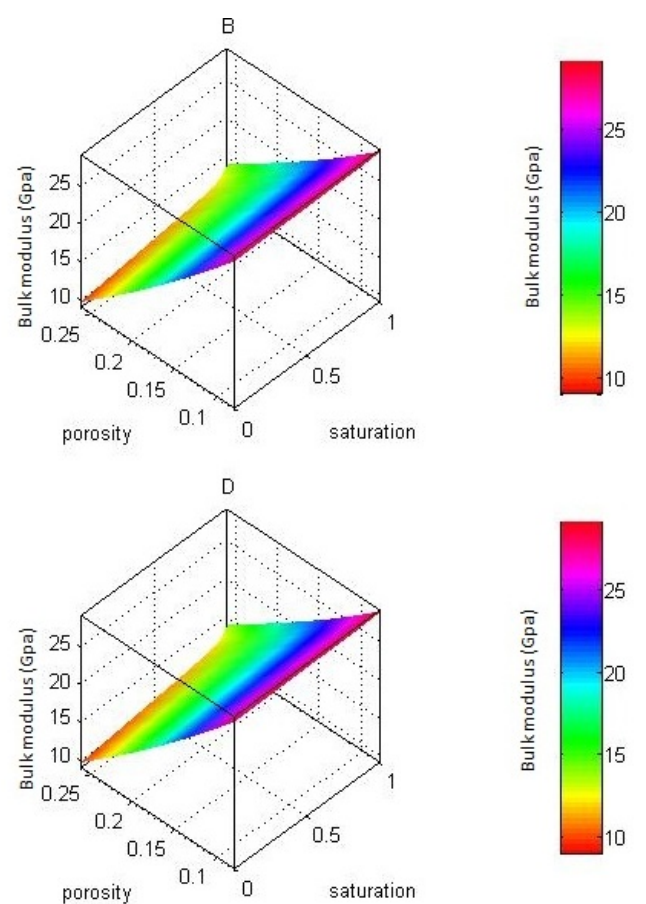

Fig. 5 Effect of fluid and porosity-related heterogeneities on the P-wave velocity of saturated sand intervals encountered in well A, B, C and D.

$14.5 \%$, the volume of shale $28 \%$, and water saturation $50 \%$. Rock physics modeling indicates the influence of pore fluid concertation at various seismic parameters. The results depict that the seismic velocities are affected by fluid's type and saturation in the Basal Sand intervals of the Lower Goru Formation.
The fluid substitution modeling indicates the decreasing trend of density and the seismic velocities due to the presence of hydrocarbon saturation. This change is more visible at maximum saturation. S-wave velocity is independent of fluid saturation in a reservoir. 

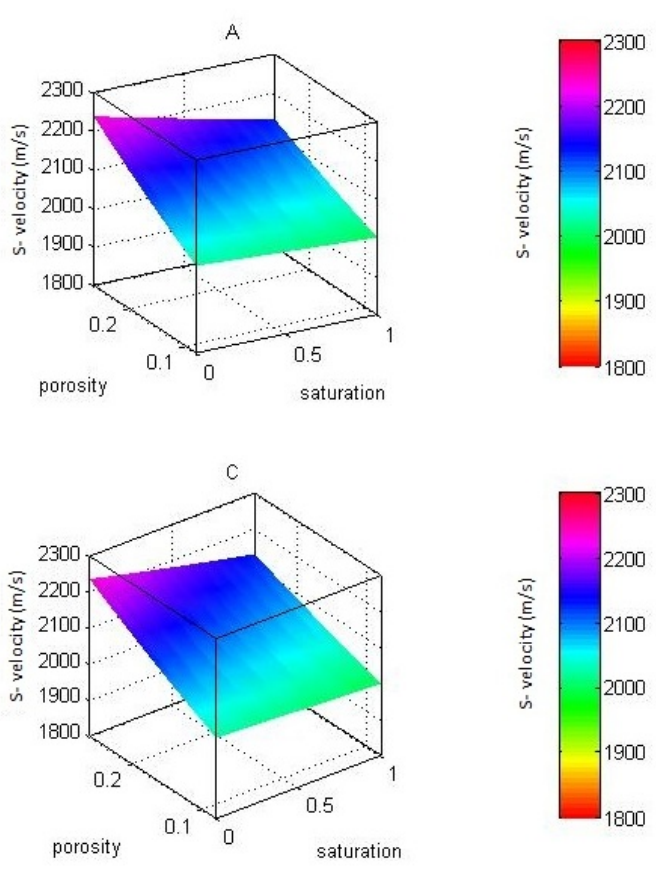
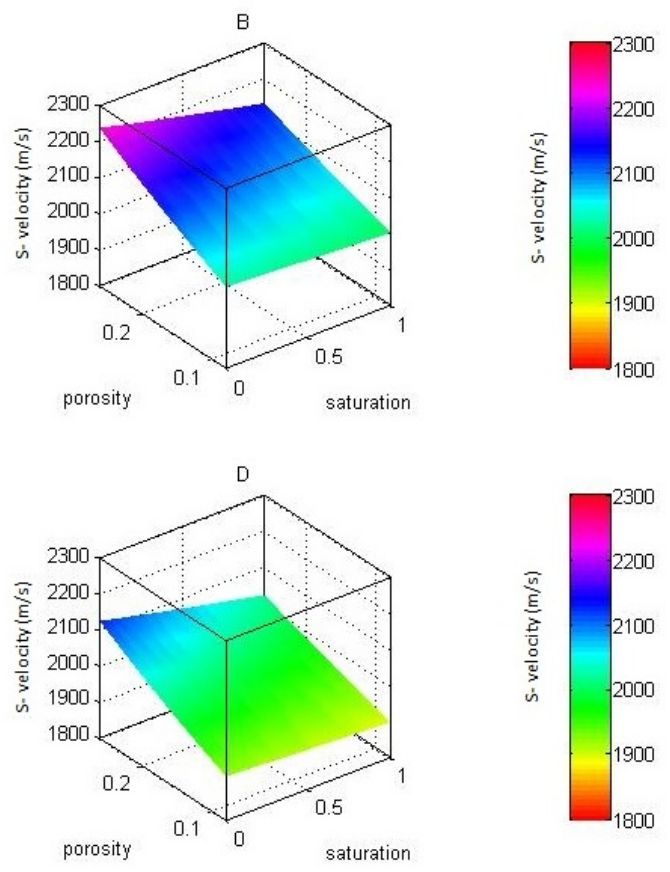

Fig. 6 Effect of fluid and porosity-related heterogeneities on the S-wave velocity of saturated sand intervals encountered in well A, B, C and D.

\section{ACKNOWLEDGMENTS}

The authors are very thankful to the DGPC of Pakistan for providing data to accomplish this study.

\section{REFERENCES}

Ahmad, N., Fink, P., Sturrock, S., Mahmood, T. and Ibrahim, M.: 2012, Sequence stratigraphy as predictive tool in Lower Goru Fairway, Lower and Middle Indus Platform, Pakistan. American Association of Petroleum Geologists Search and Dicvovery Article, 10404.

Ahmed, N., Tayyaba, K. and Khalid, P.: 2018, Assessment of reservoir rock properties from rock physics modeling and petrophysical analysis of borehole logging data to lessen uncertainty in formation characterization in Ratana Gas Field, Northern Potwar, Pakistan. J. Geol. Soc. India, 91, 6, 736-742. DOI: 10.1007/s12594-018-0932-8,

Archie, G.E.: 1942, The electrical resistivity $\log$ as an aid in determining some reservoir characteristics. Trans. Am. Inst. Mech. Eng., 146, 1, 54-62. DOI: $10.2118 / 942054-G$

Asquith, G.B. and Gibson, C.R.: 1982, Basic well log analysis for geologists. AAPG, Tulsa, USA, $216 \mathrm{pp}$.

Asquith, G.B. and Krygowski, D.: 2004, Basic well log analysis. AAPG Methods in Exploration Series, 16, $167 \mathrm{pp}$.

Azeem, T., Chun, W.Y., Khalid, P., Ehsan, M.I., Rehman, F. and Naseem, A.A.: 2018, Sweetness analysis of Lower Goru sandstone intervals of the Cretaceous age, Sawan gas field, Pakistan. Episodes, 41, 4, 235-247. DOI: $10.18814 /$ epiiugs/2018/018019

Bateman, R.M.: 1985, Open-hole log analysis and formation evaluation. International Human Resources Development Corp., 668 pp.
Clavier, C., Coates, G. and Dumanoir, J.: 1984, The theoretical and experimental basis for the 'dual water' model for the interpretation of shaly sands. Soc. Pet. Eng. J., 24, 2, 153-168. DOI: 10.2118/6859-PA

Batzle, M. and Wang, Z.: 1992, Seismic properties of pore fluids. Geophysics, 57, 11, 1396-1408.

DOI: 10.1190/1.1443207

Ehsan, M.I., Khalid, P., Ahmed, N., You, J., Liu, X. and Azeem, T.: 2016a, Seismic attenuation and velocity dispersion to discriminate gas hydrates and free gas zone, Makran offshore, Pakistan. Int. J. Geo, 7, 10201028. DOI: $10.4236 /$ ijg.2016.78077

Ehsan, M.I., Ahmed, N., Khalid, P., Liu, X.W. and Naeem, M.: 2016b, An application of rock physics modeling to quantify the seismic response of gas hydratebearing sediments in Makran accretionary prism, offshore, Pakistan. Geosci. J., 20, 321-330.

DOI: $10.1007 / \mathrm{s} 12303-015-0044-\mathrm{Z}$

Ehsan, M.I., Ahmed, N., Din, Z.U, Khalid, P. and Liu, X.W.: 2016c, An application of AVO derived attributes to analyze seismic anomalies of gas hydrate bearing sediments in Makran offshore, Pakistan. Acta. Geod. Geophys., 51, 671-683.

DOI 10.1007/s40328-015-0146-0

Hill, R.: 1952, The elastic behavior of a crystalline aggregate. Proc. Phys. Soc. A, 65, 349-354.

Hussain, M., Ahmed, N., Chun, W.Y., Khalid, P., Mahmood, A., Ahmad, S.R. and Rasool, U.: 2017a, Reservoir characterization of basal sand zone of Lower Goru formation by petrophysical studies of geophysical logs. J. Geol. Soc. India, 89, 331-338. DOI:10.1007/s12594-017-0614-y

Hussain, M., Chun, W.Y., Khalid, P., Ahmed, N. and Mahmood, A.: 2017b, Improving petrophysical analysis and rock physics parameters estimation 
through statistical analysis of basal sands, Lower Indus Basin, Pakistan. Arab. J. Sci. Eng., 42, 1, 327-337. DOI: $10.1007 / \mathrm{s} 13369-016-2128-0$

Jamil, A., Waheed, A. and Sheikh, R.A.: 2012, Pakistan's major petroleum plays - An overview of dwindling reserves. PAPG/SPE Annual Technical Conference 2009, Islamabad Pakistan, 10399.

Kazmi, A.H. and Jan, M.Q. Eds.: 1997, Geology and tectonics of Pakistan. Graphic Publisher, Karachi, 554 pp.

Khalid, P. and Ahmed, N.: 2016, Modulus defect, velocity dispersion and attenuation in partially saturated reservoirs of Jurassic sandstone, Indus Basin, Pakistan. Stud. Geophys. Geod., 60, 1, 112-29. DOI: $10.1007 / \mathrm{s} 11200-015-0804-2$

Khalid, P., Ahmed, N., Mahmood, A., Saleem, M.A. and Hassan: 2016, An integrated seismic interpretation and rock physics attribute analysis for pore fluid discrimination. Arab. J. Sci. Eng., 41, 1, 191-200. DOI: $10.1007 / \mathrm{s} 13369015-1732-8$

Khalid, P., Broseta, D., Nichita, D.V. and Blanco, J.: 2014b, A modified rock physics model for analysis of seismic signatures of low gas-saturated rocks. Arab. J. Geosci., 7, 3281-3295. DOI 10.1007/s12517-013-1024-0

Khalid, P., Ehsan, M.I., Akram, S., Din, Z.U. and Ghazi, S.: 2018, Integrated reservoir characterization and petrophysical analysis of Cretaceous sands in Lower Indus Basin, Pakistan. J. Geol. Soc. India., 91, 6, 736742. DOI: $10.1007 / \mathrm{s} 12594-018-1042-3$

Khalid, P. and Ghazi, S.: 2013, Discrimination of fizz water and gas reservoir by AVO analysis: a modified approach. Acta Geod. Geophys., 48, 3, 347-361. DOI: $10.1007 / \mathrm{s} 40328-013-0023-7$

Khalid, P., Qayyum, F. and Yasin, Q.: 2014 a, Data driven sequence stratigraphy of the cretaceous depositional system, Punjab Platform, Pakistan. Surv. Geophys., 35, 4, 1065-1088. DOI: 10.1007/s10712-014-9289-8

Killings, G., Umer, M. and Kassi, A.M.: 2002, Geology of Badin area of Pakistan. PAPG Bulletin.

Larionov, V.V.: 1969, Borehole radiometry. NEDRA, Moscow, (in Russian).

Li, S.: 2009, Characteristics of fluid substitution in porous rocks. Petrol. Sci., 6, 139-145. DOI: $10.1007 / \mathrm{s} 12182-009-0022-\mathrm{z}$

Mavko. G., Mukerji, T. and Dvorkin, J.: 2009, The rock physics hand book, tools for the seismic analysis in porous media. Cambridge University Press, Cambridge. DOI: 10.1017/CBO9780511626753

Nguyen, P.K.T. and Nam, M.J.: 2011, A review on methods for the constructing rock physics model of saturated reservoir rock for the time-lapse seismic. Geosyst. Eng., 14, 2, 95-107.

DOI: $10.1080 / 12269328.2011 .10541336$
Levaux, J. and Poupon, A.: 1971, Evaluation of water saturation in shaly formations. The Log Analyst, 12, 4, $1-2$.

Reuss, A.: 1929, Berechnung der fliessgrense von mischkristallen auf grund der plastizitatbedingung fur einkristalle. Z. Ange-Wandte Math. Mech., 25, 49-58. DOI: 10.1002/zamm.19290090104

Saxena, N., Mavko, G. and Mukerji T.: 2013, Change in effective bulk modulus upon fluid or solid in effective bulk modulus upon fluid or solid substitution. Geophysics, 78, 4. DOI: 10.1190/geo2012-0065.1

Stieber, S.J.: 1970, Pulsed neutron capture log evaluation Louisiana Gulf Coast. Fall Meeting of the Society of Petroleum Engineers of AIME 1970, Houston, Texas, SPE- 2961-MS. DOI: 10.2118/2961-MS

Telford, W.M., Geldart, L.P. and Sheriff, R.E.: 1990, Applied Geophysics. 2nd Edition, Cambridge University Press. DOI: 1017/CBO9781139167932

Voigt, W.: 1910, Lehrbuch der Kristallphysik (mit Ausschluss der Kristaloptik). Leipzig, B.G. Teubner.

Wandrey, C.J., Milici, R. and Law, B.E.: 2004, Region assessment summary South Asia Geological Survey. Digital Data Series 60, USA, 214 pp.

Wood, A.B.: 1941, A textbook of sound. G. Bell and Sons, London, $361 \mathrm{pp}$.

Yasin, Q., Baklouti, S., Khalid, P., Ali, S.H., Boateng, C.D. and Du, Q.: 2021, Evaluation of shale gas reservoirs in complex structural enclosures: A case study from Patala Formation in the Kohat-Potwar Plateau, Pakistan. J. Petrol. Sci. Eng., 198, 108225. DOI: $10.1016 /$ j.petrol.2020.108225

Zaigham, N.A. and Mallick, K.A.: 2000, Prospects of hydrocarbons associated with fossil rift structure of southern Indus basins. AAPG Bull., 84, 11, 18331848.

DOI: 10.1306/8626C3A7-173B-11D7-8645000102C1865D 